\title{
The Analysis Of Classroom Management In Teaching English
}

\author{
Sri Marmoah ${ }^{1}$ Denny Denmar ${ }^{2}$ \\ ${ }^{l}$ (Batanghari University, Jambi Indonesia) ${ }^{2}$ (Jambi University, Jambi Indonesia)
}

\begin{abstract}
The background was teachers are the key figures in learning process. They influenced fundamentally to their students' progress or lack to achieve the desired result. Teachers play very important roles in educational practice because the teachers conduct a learning teaching process, which is one of the cores of the educational activity. In addition to play their roles, teachers also need strategies and method to maintain conducive classroom environment so that the students are success in learning process and gaining the learning objectives. The purpose of this research was to find out how was the classroom management of English teacher at SMA N Kota Jambi. The design of this research was descriptive qualitative. The subject of the research was an English teacher of SMA N Kota Jambi. Data were collected by using observation, questionnaire, and interview. Based on the observation result the English teacher did the elements relate to the classroom management like teacher created and maintained the students activities in the class so the teaching efficiently and the purpose of the study can be achieved. Based on the questionnaire result, the most students in the second grade students of were enjoy to follow the teacher's activity in teaching and learning process in the classroom. Based on the interview result, the English teacher did the classroom management in the classroom as well as possible, teacher's approach describes how students acquire their knowledge of the language and made good action relate the classroom management condition which promoted successful language learning not only in physicall but also the students' mentality. Finally can be concluded that the classroom management of English teacher at SMA N Kota Jambi was good, based on the the observation, questionnaire, and interview result teacher run her job in the classroom activities.
\end{abstract}

Keywords: Analysis, Classroom Management, Teaching English

\section{INTRODUCTION}

Teachers are the key figures in learning process. They influence fundamentally to their students' progress or lack to achieve the desired result. Teachers play very important roles in educational practice because the teachers conduct a learning teaching process, which is one of the cores of the educational activity. In addition to play their roles, teachers also need strategies and method to maintain conducive classroom environment so that the students are success in learning process and gaining the learning objectives.Based on Oxford dictionary, role is actions or functions of a person in some activities. Harmer (p: 108-110), in his book divides the role of the teacher in the classroom into five major roles namely: the teacher as a controller, prompter, participant, resource, and tutor. The role that teachers take on is dependent on what they wish the students to achieve. Therefore teachers should be able to adopt variety role which facilitate learning. However some teachers only act as controller or as tutor. Of course it is not effective in some and group of age. As a controller makes sense, for example when giving explanation, organizing questions and answer works, lecturing, making announcement, or bringing a class to order. Indeed, such leadership may have an effect on a group, especially in the early stages. In many educational contexts teacher's role is the most common, and many teachers fail to go beyond it since controlling the most comfortable is a pity because by sticking to one mode, teachers deny themselves and the students, many other possibilities and modes of learning which are good not only for learning itself, but also for students' enjoyment of that learning.

Therefore classroom management and teachers' role influence the achievement of the students. Teachers have to know how to manage the class and play their roles well. It is interesting for the researcher to study about classroom management and how English teacher manage the class in learning process.

Based on the researcher's experience when the researcher got first observation, and observed the English teacher and found how the teacher manages the classroom and play her role well although sometimes she has a problem to manage the students in the class and it all will be influence for the students' achievement and the reseacher also observed the students atmosphere related to the classroom management, the reseacher also saw the teaching and learning process conducted to the classroom management, did the observation and saw how the lesson plan conducted in the classroom. In this research, wants to know how is the classroom management at the second grade of SMA N Kota Jambi. Based on the description above, the researcher was interested in conducting a research about classroom management in teaching English at SMA N Kota Jambi. 


\section{LITERATURE REVIEW}

\section{Classroom Management}

According to Mudasir (2011:1) said that management is ability or skill to get a result to reach the purpose of others people activities. Other hand according to Mudasir (2011:2) said that classroom is room that is limited by four walls for some of students to gather to follow the process of learning. Another definition of classroom management is proposed by Raka Joni in Ade Rukmana (2011:107), classroom management is the teachers' activities in the classroom that create and maintain optimal conditions for the occurrence of the learning process. Wilford in Ade Rukmana (1986:108) said that classroom management is a set of teacher's activities to create and maintain a good interpersonal relationships and socio emotional climate of the positive class. According to Ade Rukmana (2009:103) said that the successful of the students in learning was influenced by the teaching and learning strategy that had done by the teacher, because of that the teacher was forced to understand about the filosofis of teaching and learning it self.J.M. Cooper in Mudasir (2011: 2-3) said that classroom management is the whole of teachers' activity to improve the positive behavior of students and to reduce the negative behavior of students this is related to the behavioral modification of the students, the student's success in learning is largely determined by the learning strategies conducted by the teacher. Teachers are required to understand the basic components in conducting learning activities in the classroom. One of indicators a professional teacher has is the ability to manage the classroom.

From many views about classroom management above, we can conclude that classroom management is the teacher's activities in the classroom to create and maintain the students activities in the class so the teaching efficiently and the purpose of the study can be achieved.

\section{Teachers' Role}

Teachers play very important roles in educational practice. It is the teachers who conduct a learningteaching process, which the core of the educational activity. One important is instruction about academic content to promote in student the development of knowledge toward problem solving and creative effort. Mudasir (2011:65) said that teacher run their job if the teacher itself did all of activities that match with their job because of that teacher must know what is the main job of them. There are two majors role of the teacher in the classroom. The first is as management function that is to create the condition under which learning can take place. And the second is as the instructional function that is important, by variety of means and knowledge to their learners.According to Mudasir (2011:66) said that teacher's role in classroom management is very important especially in creating an interesting learning situation. The teacher is an important person in the classroom. He/she has a great influence over the students, in terms of motivation, confidence, attitudes to learning, beliefs about learning, and social morals. It has been said that a good teacher can produce great results from event the worst programmed, and that a bad teacher will make even the best programmed fail.

There are seven roles of teacher in the classroom which are very important to have to be understoodd and the teacher has to play the roles well. The first teacher's role is as a learning resource, a good teacher as a learning resource is if he/she can master the learning material. Second, teacher as a facilitator, the role of the teacher is giving the service to make easy learning activities. Third, teacher as a good manager is teacher who can create the learning climate where the students can learn in a comfortable atmosphere. Fourth, teacher as a demonstrator means the teacher can show the students everything that can make students more understand and appreciate in every messages are presented. Fifth, teacher as a guide, because the students are unique individuals and also they have differences in some aspects such as a talent, interest, abilities and so on, those differences require the teacher to act as guide. Sixth, teacher as a motivator, the learning process will be successful when students have motivation to learn so the teacher has to arise students' motivation and interest. The last is teacher as an evaluator; the role of teacher is to collect the data or information about the success of the learning that has been done, and there are two functions of evaluation. The first is for students to determine students' achievement and the second is to determine the teachers' achievement in implementing all activities that has been programmed. From many views about classroom management above, we can conclude that teacher's role in the classroom is very important to have to be understood and the teacher has to play the roles well. There are seven roles of teacher in the classroom are: teacher's role is as a learning resource, teacher as a facilitator, teacher as a good manager, teacher as a demonstrator, teacher as a guide, teacher as a motivator, and teacher as an evaluator.

\section{Teaching English}

According to Harmer (2002:423), there are many tasks that make a valuable contribution to the teaching and learning of English. Teaching is a complex and controversial profession, and the education literature is full of teaching models that present varied conceptualizations of the nature of teaching. Dornyei and Murphey in Harmer (2002:107) suggest that a group conscious teaching style involves an increasing encouragement of and reliance on the group's own resources and the active facilitation of autonomous learning 
that is in accordance with the maturity level of the group (2003:99). The core of the teaching process is the arrangement of environments within which the students can interact and study how to learn.

Bambang Setiyadi (2006:2) said that the emphasis of language teaching change by the time. Up to the quarter of the eightieth century the usual practice in schools was to translate from the second language into the first translation way already took the position of teaching grammar. Besides that Crawford (2005:10) said that teaching is more than a set of methods. Teaching well means addressing a set of objectives, for a particular group of students, at a certain point in the school year, with certain resources, within a particular time frame, in a particular school and community setting. It means finding a balance between direct instruction and orchestrating the activities of individuals and groups of students. It's mean that developing students' skills and strategies for learning, at the same time they learn the content of the curriculum.

From explanation above, can conclude that teaching English is the arrangement of environments within which the students can interact and study how to learn and more than a set of methods in English.

\section{RESEARCH DESIGN}

In this research, the researcher used descriptive qualitative. Creswell (1994:145) qualitative research involves fieldwork, the researcher physically goes to the people, setting, site, or institution to observe or record behavior in its natural setting. Moleong in Arikunto (2010:22), source of qualitative research data is the view that the form of words spoken or written in the look by researchers, and objects were observed to details, to be caught between the lines in a document or object. Besides that Sugiyono (2009:205), said that in qualitative research the problem which brought by the reseacher still unclear, unfortunately complex dark, and dynamis. Qualitative research method is based on the philosophy post positivism, used to examine the condition of natural objects, where the researcher is a key instrument, sampling the source of data is done by using purposive and snowball, gathering technique with triangulation (combined), data analysis is inductive/qualitative, and the results further emphasize the significance of qualitative research rather than generalization. Cholid Narbuko (2010:44) said that descriptive research is the research in effort to explain the problem solving in this time based on the data, so it's also provide data, analyze and implemented.

Table 1. Research Instrument

\begin{tabular}{|c|c|c|c|}
\hline No & Classroom Management & Teachers' Role & $\begin{array}{l}\text { Teaching } \\
\text { English }\end{array}$ \\
\hline 1 & $\begin{array}{l}\text { A. Planning } \\
\text { 1. Making syllabus } \\
\text { 2. Making lesson plan } \\
\text { 3. Arrangement of teaching } \\
\text { media } \\
\text { B. Actuating } \\
\text { 1. Checking attendance } \\
\text { 2. Collecting the students' work } \\
\text { 3. Ditributing of materials and } \\
\text { equipment } \\
\text { 4. Gathering the information } \\
\text { from students } \\
\text { 5. Recording of data } \\
\text { 6. Maintaining files } \\
\text { 7. Presenting the learning } \\
\text { material } \\
\text { 8. Giving the task or homework } \\
\text { C. Evaluating } \\
\text { 1.Survey from vice of } \\
\text { headmaster } \\
\text { 2. Survey from headmaster } \\
\text { 3. Survey from supervisor }\end{array}$ & $\begin{array}{l}\text { 1. Teacher as a } \\
\text { learning resources } \\
\text { 2. Teacher as a } \\
\text { facilitator } \\
\text { 3. Teacher as a } \\
\text { manager } \\
\text { 4. Teacher as a } \\
\text { demostrator } \\
\text { 5. Teacher as guide } \\
\text { 6. Teacher as a } \\
\text { motivator } \\
\text { 7. Teacher as a } \\
\text { evaluator }\end{array}$ & $\begin{array}{l}\text { 1. Teaching } \\
\text { English in } \\
\text { senior high } \\
\text { school } \\
\text { 2. The concept } \\
\text { of English } \\
\text { language } \\
\text { teaching. } \\
\text { 3. Teaching } \\
\text { English as } \\
\text { foreign } \\
\text { language }\end{array}$ \\
\hline
\end{tabular}

\section{DISCUSSION}

\section{Observation Result}

The table below show about the observation result of the second grade students in At SMA N Kota Jambi. The observation sheet consist of 18 items. 
Table 2. Observation Result

\begin{tabular}{|c|c|c|c|c|c|c|c|c|c|}
\hline \multirow[t]{2}{*}{$\begin{array}{l}\mathbf{N} \\
\mathbf{o}\end{array}$} & \multirow[t]{2}{*}{ Items } & \multicolumn{2}{|c|}{$\begin{array}{c}\text { First } \\
\text { Meeting }\end{array}$} & \multicolumn{2}{|c|}{$\begin{array}{l}\text { Second } \\
\text { Meeting }\end{array}$} & \multicolumn{2}{|c|}{$\begin{array}{l}\text { Third } \\
\text { Meeting }\end{array}$} & \multicolumn{2}{|c|}{$\begin{array}{c}\text { Fourt } \\
\text { Meeting }\end{array}$} \\
\hline & & $\begin{array}{l}\mathbf{Y} \\
\text { es }\end{array}$ & $\begin{array}{l}\mathbf{N} \\
\mathbf{o}\end{array}$ & $\begin{array}{l}\mathbf{Y} \\
\text { es }\end{array}$ & $\begin{array}{l}\mathbf{N} \\
\mathbf{o}\end{array}$ & Yes & $\begin{array}{l}\mathbf{N} \\
\mathbf{o}\end{array}$ & Yes & No \\
\hline 1 & $\begin{array}{l}\text { Teacher checks the students' } \\
\text { attendance list before start the } \\
\text { lesson. }\end{array}$ & $\sqrt{ }$ & & $\sqrt{ }$ & & $\sqrt{ }$ & & $\sqrt{ }$ & \\
\hline 2 & $\begin{array}{l}\text { Teacher collects the result of } \\
\text { students'work. }\end{array}$ & $\sqrt{ }$ & & $\sqrt{ }$ & & $\sqrt{ }$ & & $\sqrt{ }$ & \\
\hline 3 & $\begin{array}{l}\text { Teacher checks the result of } \\
\text { students' work. }\end{array}$ & $\sqrt{ }$ & & & $\sqrt{ }$ & $\sqrt{ }$ & & $\sqrt{ }$ & \\
\hline 4 & $\begin{array}{l}\text { Teacher give score to the students' } \\
\text { work. }\end{array}$ & $\sqrt{ }$ & & $\sqrt{ }$ & & $\sqrt{ }$ & & $\sqrt{ }$ & \\
\hline 5 & $\begin{array}{l}\text { Teacher save the data about } \\
\text { activities in the classroom. }\end{array}$ & & $\sqrt{ }$ & $\sqrt{ }$ & & & $\sqrt{ }$ & $\sqrt{ }$ & \\
\hline 6 & $\begin{array}{l}\text { Teacher writes the score of } \\
\text { students, work in individual or } \\
\text { group. }\end{array}$ & $\sqrt{ }$ & & $\sqrt{ }$ & & $\sqrt{ }$ & & & $\sqrt{ }$ \\
\hline 7 & $\begin{array}{l}\text { Teacher distributes the tool and } \\
\text { material fairly. }\end{array}$ & $\sqrt{ }$ & & $\sqrt{ }$ & & $\sqrt{ }$ & & $\sqrt{ }$ & \\
\hline 8 & $\begin{array}{l}\text { Teacher gives information about } \\
\text { the material that have to be done } \\
\text { by the students. }\end{array}$ & $\sqrt{ }$ & & $\sqrt{ }$ & & $\sqrt{ }$ & & $\sqrt{ }$ & \\
\hline 9 & $\begin{array}{l}\text { Teacher asks the students' work } \\
\text { that must and have finished to be } \\
\text { done. }\end{array}$ & $\sqrt{ }$ & & $\sqrt{ }$ & & $\sqrt{ }$ & & $\sqrt{ }$ & \\
\hline $\begin{array}{l}1 \\
0\end{array}$ & Teacher gives homework. & $\sqrt{ }$ & & $\sqrt{ }$ & & & $\sqrt{ }$ & & $\sqrt{ }$ \\
\hline $\begin{array}{l}1 \\
1\end{array}$ & $\begin{array}{l}\text { Teacher can work together and } \\
\text { show the friendship. }\end{array}$ & $\sqrt{ }$ & & $\sqrt{ }$ & & & $\sqrt{ }$ & $\sqrt{ }$ & \\
\hline $\begin{array}{l}1 \\
2\end{array}$ & $\begin{array}{l}\text { Teacher give warning to the } \\
\text { students in good time about the } \\
\text { trouble that may happen in the } \\
\text { classroom. }\end{array}$ & & $\sqrt{ }$ & $\sqrt{ }$ & & $\sqrt{ }$ & & $\sqrt{ }$ & \\
\hline $\begin{array}{l}1 \\
3\end{array}$ & $\begin{array}{l}\text { Teacher can share the attention } \\
\text { toward the activity that is occuring } \\
\text { in the same time. }\end{array}$ & $\sqrt{ }$ & & $\sqrt{ }$ & & $\sqrt{ }$ & & & $\sqrt{ }$ \\
\hline $\begin{array}{l}1 \\
4\end{array}$ & $\begin{array}{l}\text { Teacher asks the students to keep } \\
\text { practice, report and give respond } \\
\text { based on the activities given. }\end{array}$ & $\sqrt{ }$ & & & $\sqrt{ }$ & & $\sqrt{ }$ & $\sqrt{ }$ & \\
\hline $\begin{array}{l}1 \\
5\end{array}$ & $\begin{array}{l}\text { Teacher gives clear explanation } \\
\text { and key in conveying the lesson. }\end{array}$ & $\sqrt{ }$ & & $\sqrt{ }$ & & $\sqrt{ }$ & & $\sqrt{ }$ & \\
\hline $\begin{array}{l}1 \\
6\end{array}$ & $\begin{array}{l}\text { Teacher controls students' } \\
\text { behavior who have problems and } \\
\text { difficulties. }\end{array}$ & $\sqrt{ }$ & & $\sqrt{ }$ & & $\sqrt{ }$ & & $\sqrt{ }$ & \\
\hline $\begin{array}{l}1 \\
7\end{array}$ & $\begin{array}{l}\text { Teacher can give the solution } \\
\text { about the problem that happen in } \\
\text { the group. }\end{array}$ & $\sqrt{ }$ & & $\sqrt{ }$ & & $\sqrt{ }$ & & $\sqrt{ }$ & \\
\hline $\begin{array}{l}1 \\
8\end{array}$ & $\begin{array}{l}\text { Teachher handles the students' } \\
\text { behavior and try to find the } \\
\text { solution. }\end{array}$ & & $\sqrt{ }$ & $\sqrt{ }$ & & & $\sqrt{ }$ & & $\sqrt{ }$ \\
\hline & & $\begin{array}{l}1 \\
5\end{array}$ & 3 & $\begin{array}{l}1 \\
6\end{array}$ & 2 & 13 & 5 & 41 & 4 \\
\hline
\end{tabular}

\section{Students' Questionnaire Result}

The researcher got the data relate to the classroom management at the second grade students of SMA N Kota Jambi. The items consist of 18 questions. From 38 students, the most of the students answered always for 
the items number (1) namely teacher checks the students' attendance list before starts the lesson, number (5) teacher save the data about activities in the classroom, number (6) teacher writes the score of students' work in individual or group, number (8) teacher gives information about the material that has to be done by the students, number (10) teacher gives homework, number (14) teacher asks the students to keep practice, report and give respond based on the activities given, and the last number (15) teacher gives clear explanation and key in conveying the lesson. And items number (2) teacher collects the result of students'work, thirteen students answered always and twenty five of them answered sometimes. Items number (3) teacher checks the result of students' work, thirty three students answered always and four of them answered sometimes. For the item number (4) teacher give score to the students' work, twenty seven students answered always and eleven more answered sometimes. Next item number (7) teacher distributes the tool and material fairly twenty three students answered always, fourteen students answered sometimes and one more answered seldom. Next item related to the classroom management the item number (9) teacher asks the students' work that must and have finished to be done, thirty three students answered always, five of them answered sometimes. The item number (11) teacher can work together and show the friendship, thirty six of students answered always, two of them answered sometimes, and for the item number (12) teacher give warning to the students in a good time about the trouble that may happen in the classroom. Number (13) teacher can share the attention toward the activity that is occuring in the same time, number (16) teacher controls students' behavior who have problems and difficulties, number (17) teacher can give the solution about the problem that happen in the group the most of the students answered always for these items. And for the last item number (18) teacher handles the students' behavior and try to find the solution the most of students answered always.

\section{INTERVIEW RESULT}

Based on the result of the interview with the English teacher at SMA N Kota Jambi the result clearly shows us that the English teacher always check the attendance list before she started to study in the classroom, the English teacher said it's very important to check the attendance list of the students to know whether they came or absent. The result also show that the English teacher collected the students' work after the teaching and learning process and when teaching and learning process were occuring the English teacher didn't forget to present the learning material in teaching activity, and after that distributed the material to the students relate to the lesson in that time and and used the equipment in explaining the lesson. The researcher conclude that the English teacher did the classroom management in the classroom as well as possible, teacher's approach describes how students acquire their knowledge of the language and made good action relate the classroom management condition which promoted successful language learning not only in physicall but also the students' mentality. The teacher's action in classroom management made the students are likely to follow them willingly (and do what is asked of them) unless they have confidence in their professional abilities. Students need to believe that we know what we are doing.

\section{DISCUSSION}

Based on the observation, questionnaire, and the interview result the researcher found how the classroom management was at the second grade students of SMA N Kota Jambi. It will be describe below:

Based on the observation result during four meetings it was clearly to show us that the English teacher checked the students attendance list in every meeting. The students were viewed their existence one by one especially directed to see the readiness to follow the learning process, physically, especially mentally because the attention from the beginning will give encouragement to them to be able to follow the activities in the classroom as well. The English teacher also collected the result of students' work, examined, and assessed the result of the task teacher also evaluated the score each students and help the students to get better score related to the material that has been given. The work should be collected and given a brief comment that a high sense of appreciation can provide motivation for the work already conducted. The English teacher also checked the students' work after explaining the material in teaching process. The students asked everything relate to the material and respond by the teacher and teacher also wrote the score of the students' individual work or group. The teacher already asked them to make a group and divided them into discussion. After that the English teacher run her job to gave the score based on the students' work one by one. It could be the tecaher's reference about the students' achievement in English. Next the teacher kept them into the files as a shared responsibility that it can provide a good information for teachers and students. They were for teacher's references to continue the next teaching and learning activity. In teaching and learning process there are learning materials to be distributed fairly and proportionately so every student has opportunity to practice or use of learning aids in the learning process. The teacher used the learning aids like blackboard or whiteboard in explaining the material and to make the students more understand. When the students were studying at the laboratory the teacher and students used headphone as the learning aids to support the teaching and learning process. The teacher distributed the materials for learning and explained the materials before starting to study, tools, and material are very nessesary in teaching process 
both of them relate each others, and they can't be separated. Before the English teacher distributed the material it's her responsible to give the information about the material that has to be done by the students so the students were not confuse about the material.

From the questionnaire result the researcher got the data relate to the classroom management at the second grade students of SMA N Kota Jambi. From all of the students answered "always" for the item teacher checks the students' attendance before starting the lesson, it's good because the English teacher want to know the students come or not. Next all of the students also answered "always" for the item teacher save the data about activities in the classroom, every activity is saved by the teacher. Next item teacher writes the score of students" work in individual or group, the most of them answered "always" this is good for the teacher and students, the score is very important to know how far their ability in understanding the material that has been given by the teacher. Next item, teacher asks the students to keep practice, report and give respond based on the activities given, it was good result from the students all of them answered "always". And next item, teacher collects the result of students'work after explain the material, it's the teacher turn in collecting the result of students' work. The students who didn't collect the task or work got the punishment from the teacher. Next item, the teacher checks the result of students' work after collect the students' work, in this oppurtunity the English teacher also gave comment and statement to the students relate to the score. The teacher statement about something that put forward by the students are necessary, well in responses, comments, or others. But, should be avoided the things that show the dominance of the teacher, for example with comments or statement that contains of treats like: "I wait until you shut up", "I am or you are out?" or" who is not happy with my lesson, please come out!" For the next item teacher give score to the students' work, it showed a good result in starting the learning process. The teacher focus on the group's attention to a task by giving some signs, such as creating or giving prior to introducing the situation of the object, question, or topic, by randomly selecting students to respond

Based on the questionnaire result the researcher conclude that the most students in the second grade students were enjoy to follow the teacher's activity in teaching and learning process in the classroom. In the classroom teacher gave a guidance that was clear in giving the lesson, so there was no confusion on the students themselves. Direction and instruction could be performed on all members of the class, to small groups, or individuals with language and clear purpose.

Based on the result of the interview with the English teacher at SMA N Kota Jambi the result clearly show us that the English teacher always checked the attendance before starts to study in the classroom. The English teacher said it's very important to check the attendance of the students to know whether they came or absent in pre activity. In the same time directly the English teacher asked the students condition and pay attention for them. In this case teacher gave the reward and punishment based on the students' achievement. The English teacher also paid attention to the classroom situation if the classroom is dirty, teacher asked them to clean it. The result also show that the English teacher collected the students' work after the teaching and learning process, and when teaching and learning process was occuring the English teacher didn't forget to present the learning material.

The English teacher distributed the material to the students relate to the lesson, in that time the material came from the English text book, students' worksheet, and others references can show learning process that can be learned by students who normally have a speed of above average learning of other students. Some students need a special attention, for example by providing enrichment materials to indicate the source of learning related to the learning material. In order to carry out the role of facilitator in the learning process, the teacher must understand in particular matters relate to the use of various media and sources of learning, in teaching process. After explaining the lesson the English teacher also gather the information from the students relate to the topic that they discuss in the classroom and after that they were discussing it together. The English teacher also didn't forget to record of the data and maintained the files relate to the classroom activity to support her teaching process in the classroom. Next result, after explaining the material to the students the English teacher also didn't forget to give the task relate to the material and share it together teacher then gave the homework to the students.

Based on the interview result the researcher conclude that the English teacher did the classroom management in the classroom as well as possible, teacher's approach describes how students acquire their knowledge of the language and made good action relate the classroom management condition which promoted successful language learning not only in physicall but also the students' mentality. The teacher's action in classroom management made the students are likely to follow them willingly and do what is asked of them unless they have confidence in their professional abilities. Students need to believe that we know

\section{CONCLUSION}

Based on evidences which were provided in findings and discussions, the researcher presents several items of conclusion as follows :The classroom management at the second grade students of SMA N Kota Jambi was good, based on the the observation, questionnaire and interview result, teacher ran her job in the classroom 
activities, firstly teacher has to check the students' attendance before starting the lesson. Teacher collected the result of students'work, teacher checked the result of students' work, teacher gave score to the students' work, teacher kept the data about activities in the classroom. Secondly for the while activity teacher wrote the score of students' work in individual or group, teacher distributed the tool and material fairly, teacher gave information about the material that had to be done by the students, teacher asked the students' work that must and had finished to be done, teacher gave homework, teacher could work together and shawn the friendship, teacher gave warning to the students in good time about the trouble that may happen in the classroom. Teacher could share the attention toward the activity that was occuring in the same time, asked the students kept practice, reported and gave respond based on the activities given, teacher gave clear explanation and key in conveying the lesson. Thirdly for post activity teacher controls students' behavior who had problems and difficulties, teacher given the solution about the problem that happened in the group, and teacher handles the students' behavior and try to find the solution.

\section{Suggestion}

After analyzing the data and making the conclusion, the researcher provides suggestions in exlporing how is the classroom management at the second grade students of SMA N Kota Jambi.

Firstly, the teacher should have a wide knowldge about the classroom management and it can be implemented in the classroom. Secondly, teacher should have the ability related with creating and maintaining of optimal condition for learning process, and ability relate to the competence of teacher in taking the initiative and control the subject in order to conductive learning environment can be reached in teaching and learning process. Thirdly, hopely the teacher shouldn't forget to run the classroom activities, and finally the teacher should run her role as a teacher to support the successful of classroom management and she should has a good relationship with their students.

\section{REFERENCES}

[1.] Arikunto, 2010. Prosedur Penelitian. Edisi Revisi 2010. Jakarta: PT. Rineke Cipta

[2.] Bogdan, R. C. \& Biklen, S. K. (1982). Qualitative Research for Education: An Introduction to the Theory and Methods. Boston : Allyn and Bacon, Inc.

[3.] Cholid Narbuko, dkk, 2010. Metodologi Penelitian. Jakarta: Sinar Grafika Offset.

[4.] Crawford Alan, dkk, 2005. Teaching and Learning Strategies for the Thinking Classroom. New York: The international Debate Education Association 400 West 59th Street.

[5.] Harmer, J, 2011. The Practice of English Language Teaching. New York: Pearson Education Limited.

[6.] Iskandar, 2012. Penelitian Tindakan Kelas. Jakarta: Referensi (GP Press Group).

[7.] Cresswell, John W. 1994. Research Design Qualitative \& Quantitative Approach. New Delhi: SAGE Publication.

[8.] Mudasir, 2009. Manajemen Kelas. Yogyakarta: Nusa Media.

[9.] Raka Joni, 2010. Management Kelas. Jakarta: Refika Aditama.

[10.] Rukmana Ade \& Asep Suryana, 2011. Manajemen Kelas. Jakarta.

[11.] Setiyadi Bambang, 2006. Teaching English as Foreign Language. Yogyakarta: Graha Ilmu.

[12.] Sugiyono, 2009, Metode Penelitian Kuantitatif kualitatif dan R\&D. Edisi Revisi V. Jakarta: IKAPI.

[13.] htpp://www.nwrel.orged/request/oct00/textonly.html.[Accessed on Internet at 29 November 2012]

[14.] Ten Have, Paul. (2004). Understanding Qualitative Research and Ethnomethodology. Sage Publication. 